\title{
Three-dimensional bone tissue substitute based on a human mesenchymal stem cell culture on a nanofiber carrier and inorganic matrix
}

\author{
Martin Krbec ${ }^{1}$, Lukáš Plíštil ${ }^{2}$, Eva Matoušková2, Václav Mandys ${ }^{3}$, Jakub Ježek ${ }^{1}$, \\ Markéta Sedlinská ${ }^{4}$, Valér Džupa ${ }^{1}$ \\ University Hospital Královské Vinohrady, 'Department of Orthopaedics and Traumatology, \\ ${ }^{2}$ Centre for Applied Bioimplantology, ${ }^{3}$ Institute of Pathology, Prague, Czech Republic \\ ${ }^{4}$ University of Veterinary and Pharmaceutical Sciences Brno, Faculty of Veterinary Medicine, \\ Equine Clinic, Department of Reproduction, Brno, Czech Republic
}

Received December 4, 2015

Accepted February 10, 2016

\begin{abstract}
The aim was to construct a composite structure for bone tissue substitute on the basis of a degradable composite of an organic nanofiber carrier and an inorganic matrix in $3 \mathrm{D}$, and to achieve subsequent colonisation by differentiated human mesenchymal stem cells (hMSC) towards osteocytes. We developed an active bone tissue substitute using nanofiber technology for a polycaprolactone (PCL) scaffold with the addition of hydroxyapatite and the colonisation of both components with hMSC with the ability of differentiation towards osteocytes. The constructed composition included the components necessary for bone healing (inorganic and cellular) and it also forms a spatially-oriented 3D structure. We used polycaprolactone Mw 70,000 with electrostatic spinning for the formation of nanofibers using a modified Nanospider ${ }^{\mathrm{TM}}$ method. For the inorganic component we used orthophosphate-calcium silicate with a crystal size of 1-2 mm which the nanofiber membrane was coated with. Both components were connected together with a tissue adhesive based of fibrin glue. Cultivated hMSC cells at a concentration of $1.2 \times 10^{4} / \mathrm{cm}^{2}$ were multiplied in vitro and then cultivated in the expansion medium. HMSC overgrew both the PCL membrane and the Si-CaP crystals. After colonisation with cultivated cells, this composite 3D structure can serve as a three-dimensional bone tissue replacement.
\end{abstract}

Bone substitution, polycaprolacton, nanotissue, biodegradable scaffold, hydroxyapatite, hMSC

The aim of the work was to construct a 3D composite structure for a bone tissue substitute based on a degradable composite of organic nanofiber carrier and inorganic matrix and to achieve subsequent colonisation towards osteocytes by differentiated human mesenchymal stem cells (hMSC).

This device will be useful as a bone tissue substitute for needs in the field of orthopaedics and traumatology. It can be used, in particular, for treatment of bone defects, namely after injuries accompanied by bone loss, after resection surgeries in orthopaedics e.g. after removal of malignant tumours and for the treatment of unhealed bone fractures and nonunions. It can also be used to potentiate the healing of fractures.

The subject of bone healing and substitution of bone tissue is still being explored (Venugopal et al. 2008; 2010). The current commonly used method is the use of bone cement based on polymethyl methacrylate or metal substitutes on the basis of titanium and its alloys, recently on the basis of porous tantalum (trabecular metal). The disadvantage of these methods is the fact that it is a foreign material which is not structurally integrated into the bone. It has different elasticity and strength; it increases the risk of complications such as infection and the risk of mechanical failure.

Another possibility is the use of autologous or allogeneic bone grafts. These bone transplants are for many reasons considered obsolete because they are limited by the volume of useable material (autologous) and associated with defined risks of complications (allogeneic), such as the risk of infectious disease transmission from donor to recipient (similar to e.g. blood transfusion) or slow healing. 
Synthetic or inorganic bone tissue substitutes are used in practice but their efficiency is questionable based on the available data in the literature and they are suitable only for limited indications.

Inorganic bone tissue substitutes on the basis of hydroxyapatite, which is the main component of the mineral portion of the bone matrix, have recently been used in practice mainly for their mechanical strength. Substitutes based on Ca sulphate, $\mathrm{Ca}$ phosphate and silicates are being tested. The inorganic component adds strength and, after implantation, it is in the optimal case colonised and slowly intergrown by the recipient's own bone cells, so that in time bone remodelling occurs. A new approach in the development of active bone tissue substitute is the use of nanofiber technology to create the carrier (Parizek et al. 2012; Rim et al. 2013; Shalumon et al. 2013; Amler et al. 2014 ) in combination with the addition of hydroxyapatite and using the possibility of colonisation of these components with suitable cells capable of differentiating towards osteocytes (Martins et al. 2010; Ba Linh et al. 2013; Gandhimathi et al. 2013; Lyu et al. 2013; Gahawar et al. 2014; Novotna et al. 2014).

The initial intention was based on the requirement that the constructed composition should include all the components necessary for bone healing (inorganic and cellular) and that it should also form a standard spatially-oriented 3D structure, mechanically durable and processable for application to bone defects. For this purpose, a nanofiber biodegradable carrier and fibrin glue were used in addition to components for bone healing.

\section{Materials and Methods}

Chemicals and feedstock

Polycaprolactone (PCL), Mw 70,000 (Scientific Polymer Products, USA); formic acid, acetic acid, standard solutions May-Grünwald, Giemsa-Romanowski (Penta, Czech Republic); Actifuse ${ }^{\mathrm{TM}}$ microgranules (porous crystals of 1-2 mm in size, orthophosophate and calcium silicate, silicon content $0.8 \%$, ApaTech, UK); Artiss (human fibrin sealant, Baxter, USA); PBS, alizarin red S (P-Lab, Czech Republic); dexamethasone, ascorbyl-2phosphate, glycerol-2-phosphate, Triton X-100, $\mathrm{MgCl}_{2}$ (Sigma-Aldrich, USA); gene expression assays RUNX2, BMP2, IBSP, GAPDH, AND BGLAP (Life Technologies, USA).

\section{Preparation of the organic carrier}

As the material for nanofiber formation, we used the synthetic polyester polycaprolactone known for its biodegradability within several months (Salgado et al. 2012) and biocompatibility to hMSC (Valonen et al. 2010; Ko et al. 2015). The prepared nanofiber membrane from PCL had a basis weight of $36 \mathrm{~g} / \mathrm{m}^{2}$, thickness of $200 \mu \mathrm{m}$ and a fibre diameter of $110 \pm 40 \mathrm{~nm}$ (Plate IX, Fig 1, and Fig 2).

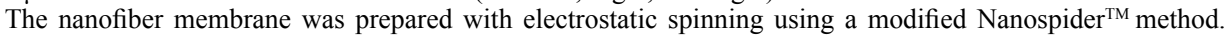
The method is based on simultaneous formation of charged polymer solution streams on the surface of a thin wire electrode (Forward et al. 2012). The polymer solution was prepared as follows: $18.0 \mathrm{~g}$ of polycaprolactone (PCL) were added to a stirred mixture of formic acid $(20.5 \mathrm{~g})$ and acetic acid $(61.5 \mathrm{~g})$. The mixture was stirred at $50{ }^{\circ} \mathrm{C}$ until complete polymer dissolution occurred (about $3 \mathrm{~h}$ ). The polymer solution was then cooled to room temperature and spun at a voltage of $80 \mathrm{kV}$; electrode distance of $150 \mathrm{~mm}$; relative air humidity of $33 \%$ at $22{ }^{\circ} \mathrm{C}$. As the collecting base material, we used an antistatic polypropylene spunbond (Atex, IT, 20-30 g/m²) which was moving at $14 \mathrm{~mm} / \mathrm{min}$. The nanofiber membrane was then washed for 7 days with tissue water to remove residual solvents, then sterilised for $30 \mathrm{~min}$ under UV-C radiation and subsequently seated in sterile round handle Cellcrown6 $\left(5 \mathrm{~cm}^{2}\right.$; Scaffdex, FIN). The nanofiber membrane was designated hereinafter as the component $\alpha$ of the composite.

\section{Preparation of the PCL-Si-CaP composite}

As the inorganic component of the composite (designated $\beta$ ), we used a commercially available microcrystalline product Actifuse (silicon content $0.8 \%$ ) with a crystal size of 1-2 mm which the surface of PCL nanofiber membrane was coated with. A sterile fibrin glue Artiss $(200 \mu 1)$ was uniformly added to the membrane surface drop by drop and then orthophosphate-calcium silicate (Si-CaP Actifuse, $200 \mathrm{mg}$ ) crystals were regularly placed there. The fibrin was left to solidify for $1 \mathrm{~h}$.

Thus we created a nanofiber-Si-CaP composite in a $3 \mathrm{D}$ form from the components $\alpha$ and $\beta$. 


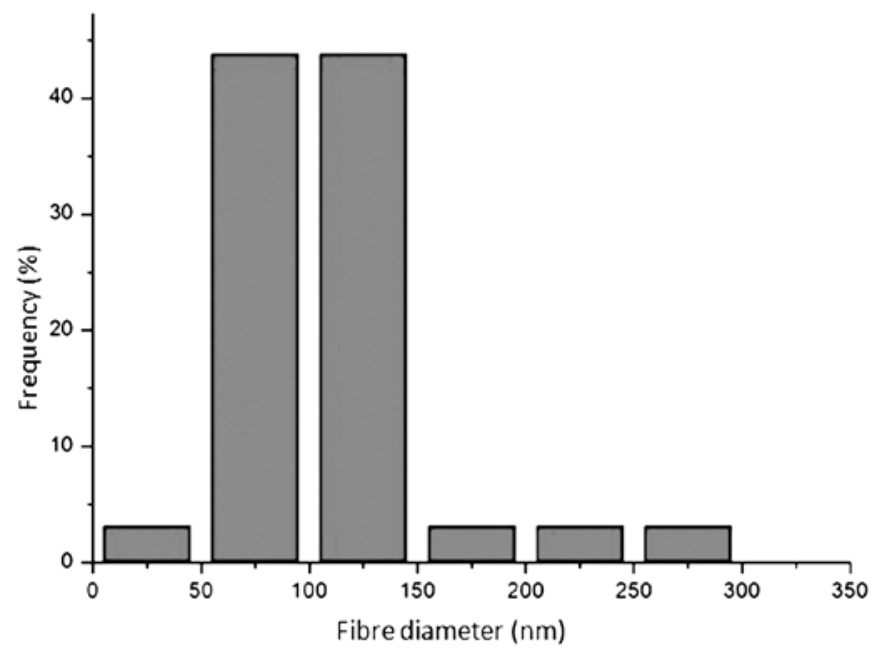

Fig. 2. A frequency diagram showing the distribution of fibre diameters

Both components were connected together with a tissue adhesive on the basis of fibrin (Artiss). The overall appearance of the composite is shown in Fig. 3 a,b (Plate IX).

Preparation of cell suspension and cultivation

Human mesenchymal stem cell isolation

Human MSC were obtained from adipose tissue samples removed during surgeries. The tissue sample $\left(1 \mathrm{~cm}^{3}\right)$ was cut and immersed in $0.1 \%$ collagenase I (Roche) (dissolved in H-MEM medium with 10\% serum) for $4 \mathrm{~h}$ at $37^{\circ} \mathrm{C}$. The tissue was then stretched several times with a pipette until it disintegrated. The cell suspension was centrifuged $(600 \times g, 10 \mathrm{~min})$, the supernatant removed and the cell pellet re-suspended and seeded onto 1-2 culture flasks with the surface of $25 \mathrm{~cm}^{2}$.

Human mesenchymal stem cell cultivation

Human MSC at a concentration of $1.2 \times 10^{4}$ cells $/ \mathrm{cm}^{2}$ were seeded onto composites fixed in Cellcrown6 and cultivated in 6-well plates (Nunc, DEN) in $5 \mathrm{ml}$ of expansion or differentiation medium at $37{ }^{\circ} \mathrm{C}, 3.5 \% \mathrm{CO}$ for 7,14 , and 21 days. The same conditions were used also for the control samples cultivated on the bottom of culture dishes. The medium was changed every 3 days.

Composition of media: expansion - H-MEM enriched with non-essential amino acids, $0.12 \mathrm{~g} / 1 \mathrm{of}$ sodium pyruvate, $1 \mathrm{~g} / 1 \mathrm{NaHCO}_{3}, 10 \%$ of bovine serum, $2 \%$ of foetal bovine serum, $1 \mathrm{~g} / 1 \mathrm{glutamine}, 2.5 \mathrm{ng} / \mathrm{ml} \mathrm{EGF}$, $200 \mu \mathrm{g} / \mathrm{ml}$ penicillin, $100 \mu \mathrm{g} / \mathrm{ml}$ streptomycin; differentiation medium - expansion medium enriched with $100 \mathrm{nM}$ dexamethasone, $50 \mu \mathrm{g} / \mathrm{ml}$ ascorbyl-2-phosphate, $10 \mathrm{mM}$ glycerol-2-phosphate.

To visualise the cells, we used the standard May-Grünwald and Giemsa-Romanowski staining. Formation of hydroxyapatite in control samples was detected by alizarin red staining $\left(2 \%\right.$ solution, $\left.\mathrm{pH} \sim 4.5,15 \mathrm{~min}, 25^{\circ} \mathrm{C}\right)$ after formalin fixation (4\% solution in PBS, $15 \mathrm{~min}$ ).

The quality of hMSC was analysed by their activity against antigen of the surface proteins CD34, CD73, CD90, CD105; and by their ability to differentiate into osteoblasts. Human MSC grown on composites were cultivated in vitro in a differentiation medium for osteoblasts for 21 days. The differentiation was proved microscopically, by an increased production of alkaline phosphatase (ALP) and the presence of mRNA coding ossification proteins (osteocalcin, osteopontin, runt-related transcription factor 2).

The cellular component of the future composite was designated as component $\gamma$.

\section{Microscopy}

Morphology of the nanofiber membrane was analysed using a scanning electron microscope FEI Quanta 200 (with a secondary electron detector Everhart-Thornley) (Plate IX, Fig. 1); samples were covered with a thin layer of gold and observed under high vacuum. The fibre diameter was determined using NIS Elements 4.0 (Laboratory Imaging, Czech Republic). Three samples were taken from the nanofiber material and at least 50 individual fibres were measured in them.

The composite material after colonisation of hMSC was then viewed using an Olympus IX71 optical microscope (Plate X, Fig. 4a,b). 


\section{Results}

The solution subject is a device for use as a 3D composite bone tissue substitute consisting of three components (Table 1).

Table 1. The three components of the 3D composite bone tissue substitute.

\begin{tabular}{ll}
\hline Component & Description \\
\hline$\alpha$ & Nanofiber membrane on the basis of biocompatible polycaprolactone \\
$\beta$ & Porous inorganic material - orthophosphate-calcium silicate crystals \\
$\gamma$ & Cultivated human mesenchymal stem cells differentiated into osteocytes \\
& in the form of suspension \\
\hline
\end{tabular}

Component $\alpha$ was a nanofiber carrier (membrane) which was prepared by electrostatic spinning of polymeric solution of biodegradable and hMSC biocompatible polycaprolactone (PCL) using a modified Nanospider ${ }^{\mathrm{TM}}$ method. Component $\beta$ was composed of a commercially available inorganic porous matrix. It comprised orthophosphate-calcium silicate (Si-CaP, Actifuse, $200 \mathrm{mg}$ ) crystals. The crystals were fixed on the surface of the nanofibre membrane with a fibrin glue. Component $\gamma$ consisted of cultivated hMSC at a concentration of $1.2 \times 10^{4}$ cells $/ \mathrm{cm}^{2}$. The cells derived from adipose tissue were first multiplied in vitro and then cultivated in the presence of the composite in the expansion medium.

In the first stage, toxicity of the PCL-Si-CaP composite for hMSC was observed. The cells derived from adipose tissue were first multiplied in vitro and then cultivated in the presence of the composite in the expansion medium. After seven days of cultivation, the composite was stained, its components disintegrated and cells on individual components of the composite were visualised (Plate XI, Figs 5 and 6). It is evident from the microscopic pictures that hMSC overgrew both the PCL membrane and Si-CaP crystals. It was also found that hMSC were not able to penetrate through the nanofiber membrane. The hMSC differentiation into osteocytes was demonstrated microscopically by an increased production of alkaline phosphatase (ALP) (Fig. 7) and the presence of

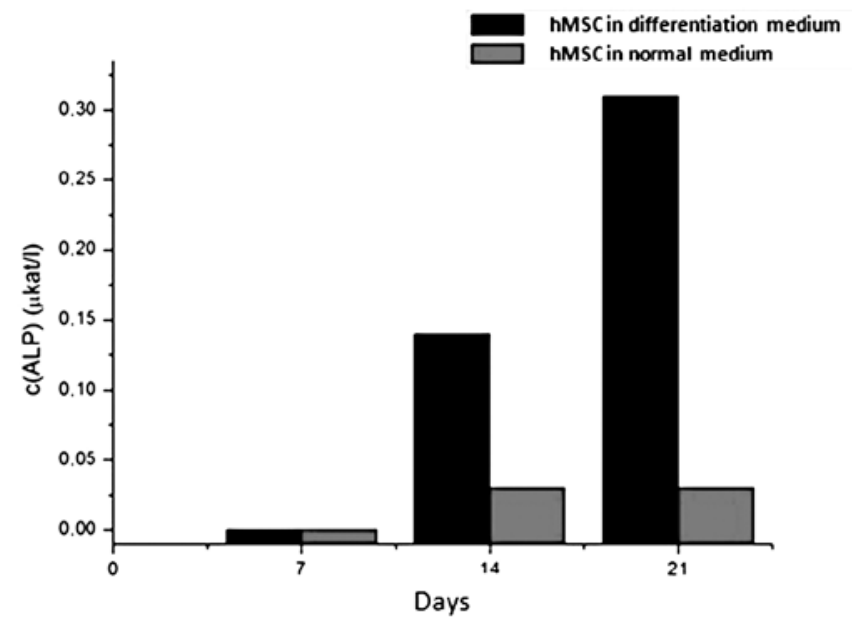

Fig. 7. The results of the spectrophotometric analysis of ALP present in the hMSC samples 
mRNA coding the ossification proteins. Figure 7 shows that the concentration of ALP increased in the osteo-differentiation medium which is considered one of the proofs of differentiation of MSC into osteoblasts.

After colonisation with cultivated cells the composite structure prepared in this way can serve as a three-dimensional bone tissue replacement (Plate XI, Figs 5 and 6).

\section{Discussion}

Essential requirement for the creation of a bone tissue substitute is the choice of a suitable material with good structural and mechanical properties that is not toxic to cell culture, does not prevent cell proliferation, differentiation and formation of new bone tissue and, in particular, is fully biodegradable (Rodrigues et al. 2012; Araujo et al. 2015). We chose a combination of two materials: a nanofibre membrane prepared from a biodegradable and biocompatible polymer (Eap et al. 2012, 2015; Guo et al. 2013) and an inorganic substrate - orthophosphatecalcium silicate ( $\mathrm{Si}-\mathrm{CaP}$ ). This selection was based on the following reasons: $\mathrm{Si}-\mathrm{CaP}$ is the active ingredient of commercially available bone tissue replacements; its presence is shown to promote angiogenesis and osteogenesis; it is further resorbed to hydroxyapatite in bone tissue (Hing et al. 2007); and the nanofiber morphology is very similar to the structure of the extracellular matrix, thereby promoting cell proliferation (Franco et al. 2014). The biodegradable polymer gives the cells a temporary support when colonising the substitute and it decomposes after a certain time, leaving only the resorbed inorganic component with a layer of bone tissue cells in the bone tissue (Bhattacharyya et al. 2009).

Unlike some previous works (Venugopal et al. 2008; Prosecka et al. 2012), we created a nanofiber-Si-CaP composite in a $3 \mathrm{D}$ form.

One of the conditions for successful bone repair is the growth rate and a sufficient number and quality of hMSC in the anticipated place of healing (Muschler et al. 2001; Prosecka et al. 2011; De Santis et al. 2015). In bone defects, however, the activity of hMSC is lower and it is necessary to look for ways to stimulate this process in bone healing (Necas et al. 2010). One possibility is to enrich the place of healing with autologous hMSC or bone substitute with already cultured autologous hMSC (Crha et al. 2009) which is the method we chose, too.

The composite structure prepared in this way, with the carrier construction using nanotechnology for the processing of organic biodegradable materials in combination with an organic matrix containing mineral resources essential for osteogenesis, can after colonisation with cultivated cells serve as a three-dimensional bone tissue replacement with the potential for rapid reconstruction and remodelling. It can be mechanically processed into a multilayer structure (Plate IX, Fig. 3b) that can be used for filling bone defects or strengthening pseudoarthroses by the method of biological stimulation, replacing open spongioplasty to accelerate the healing of pseudoarthroses.

Although these promising features of the material were proved experimentally in vitro, it is necessary to investigate its use in bone defect healing in an animal model in upcoming in vivo experiments on miniature pigs. Only thereafter a study for in vivo testing in humans would be designed.

\section{Acknowledgement}

This work was supported by the Internal Grant Agency of Ministry of Health of the Czech Republic IGA NT 14438 .

\section{References}

Amler E, Filová E, Buzgo M, Prosecká E, Rampichová M, Nečas A, Nooeaid P, Boccaccini AR 2014: Functionalized nanofibers as drug-delivery systems for osteochondral regeneration. Nanomedicine 9: 1083-1094 
Araujo JV, Carvalho PP, Best SM 2015: Electrospinning of Bioinspired Polymer Scaffolds. Adv Exp Med Biol 881: $33-53$

Ba Linh NT, Min YK, Lee BT 2013: Hybrid hydroxyapatite nanoparticles-loaded PCL/GE blend fibers for bone tissue engineering. J Biomater Sci Polym Ed 24: 520-538

Bhattacharyya S, Kumbar SG, Khan YM, Nair LS, Singh A, Krogman NR, Brown PW, Allcock HR, Laurencin CT 2009: Biodegradable polyphosphazene nanohydroxyapatite composite nanofibers: scaffolds for bone tissue engineering. J Biomed Nanotechnol 5: 69-75

Crha M, Nečas A, Srnec R, Janovec J, Stehlík L, Raušer P, Urbanová L, Plánka L, Jančář J, Amler E 2009: Mesenchymal stem cells in bone tissue regeneration and their application in bone defect healing. Acta Vet Brno 78: 635-642

De Santis R, Russo A, Gloria A, D’Amora U, Russo T, Panseri S, Sandri M, Tampieri A, Marcacci M, Dediu VA, Wilde CJ, Ambrosio L 2015: Towards the design of 3D fiber-deposited poly( $\varepsilon$-caprolactone)/irondoped hydroxyapatite nanocomposite magnetic scaffolds for bone regeneration. J Biomed Nanotechnol 11: 1236-1246

Eap S, Ferrand A, Palomares CM, Hébraud A, Stoltz JF, Mainard D, Schlatter G, Benkirane-Jessel N 2012: Electrospun nanofibrous 3D scaffold for bone tissue engineering. Biomed Mater Eng 22: 137-141

Eap S, Morand D, Clauss F, Huck O, Stoltz JF, Lutz JC, Gottenberg JE, Benkirane-Jessel N, Keller L, Fioretti F 2015: Nanostructured thick 3D nanofibrous scaffold can induce bone. Biomed Mater Eng 25(1 Suppl): 79-85

Franco RA, Sadiasa A, Seo HS, Lee BT 2014: Biphasic calcium phosphate loading on polycaprolactone/ poly(lacto-co-glycolic acid) membranes for improved tensile strength, in vitro biocompatibility, and in vivo tissue regeneration. J Biomater Appl 28: 1164-1179

Forward KM, Rutledge GC 2012: Free surface electrospinning from a wire electrode. Chem Eng J 183: 492-503

Gaharwar AK, Mukundan S, Karaca E, Dolatshahi-Pirouz A, Patel A, Rangarajan K, Mihaila SM, Iviglia G, Zhang H, Khademhosseini A 2014: Nanoclay-enriched poly( $\varepsilon$-caprolactone) electrospun scaffolds for osteogenic differentiation of human mesenchymal stem cells. Tissue Eng Part A 20: 15-16

Gandhimathi C, Venugopal J, Ravichandran R, Sundarrajan S, Suganya S, Ramakrishna S 2013: Mimicking nanofibrous hybrid bone substitute for mesenchymal stem cells differentiation into osteogenesis. Macromol Biosci 13: 696-706

Guo Q, Li X, Ding Q, Li D, Zhao Q, Xie P, Tang X, Luo F, Qian Z 2013: Preparation and characterization of poly(pluronic-co-L-lactide) nanofibers for tissue engineering. Int J Biol Macromol 58: 79-86

Hing KA, Wilson LF, Buckland T 2007: Comparative performance of three ceramic bone graft substitutes. Spine J 7: 475-490

Ko YM, Choi DY, Jung SC, Kim BH 2015: Characteristics of plasma treated electrospun polycaprolactone (PCL) nanofiber scaffold for bone tissue engineering. J Nanosci Nanotechnol 15: 192-195

Lyu S, Huang C, Yang H, Zhang X 2013: Electrospun fibers as a scaffolding platform for bone tissue repair. J Orthop Res 31: 1382-1389

Martins A, Pinho ED, Correlo VM, Faria S, Marques AP, Reis RL, Neves NM 2010: Biodegradable nanofibersreinforced microfibrous composite scaffolds for bone tissue engineering. Tissue Eng Part A 16: 3599-3609

Muschler GF, Nitto H, Boehm CA, Easley KA 2001: Age- and gender-related changes in the cellularity of human bone marrow and the prevalence of osteoblastic progenitors. J Orthop Res 19: 117-125

Nečas A, Proks P, Urbanová L, Srnec R, Stehlík L, Crha M, Raušer P, Plánka L, Amler E, Vojtová L, Jančář J 2010: Healing of large segmental bone defect after implantation of autogenous cancellous bone graft in comparison with hydroxyapatite and $0.5 \%$ collagen scaffold in combination with mesenchymal stem cells. Acta Vet Brno 79: 607-612

Novotna K, Zajdlova M, Suchy T, Hadraba D, Lopot F, Zaloudkova M, Douglas TE, Munzarova M, Juklickova M, Stranska D, Kubies D, Schaubroeck D, Wille S, Balcaen L, Jarosova M, Kozak H, Kromka A, Svindrych Z, Lisa V, Balik K, Bacakova L 2014: Polylactide nanofibers with hydroxyapatite as growth substrates for osteoblast-like cells. J Biomed Mater Res A 102: 3918-3930

Parizek M, Douglas TE, Novotna K, Kromka A, Brady MA, Renzing A, Voss E, Jarosova M, Palatinus L, Tesarek P, Ryparova P, Lisa V, dos Santos AM, Warnke PH, Bacakova L 2012: Nanofibrous poly(lactide-coglycolide) membranes loaded with diamond nanoparticles as promising substrates for bone tissue engineering. Int J Nanomedicine 7: 1931-1951

Prosecka E, Rampichova M, Vojtova L, Tvrdik D, Melcakova S, Juhasova J, Plencner M, Jakubova R, Jancar J, Necas A, Kochova P, Klepacek J, Tonar Z, Amler E 2011: Optimized conditions for mesenchymal stem cells to differentiate into osteoblasts on a collagen/hydroxyapatite matrix. Journal of Biomedical Materials Research Part A 99A: 307-315

Prosecká E, Buzgo M, Rampichová M, Kocourek T, Kochová P, Vysloužilová L, Tvrdík D, Jelínek M, Lukáš D, Amler E 2012: Thin-layer hydroxyapatite deposition on a nanofiber surface stimulates mesenchymal stem cell proliferation and their differentiation into osteoblasts. J Biomed Biotechnol 428503. Epub Jan 29, 2012

Rim NG, Shin CS, Shin H 2013: Current approaches to electrospun nanofibers for tissue engineering. Biomed Mater 8: 014102

Rodrigues MT, Martins A, Dias IR, Viegas CA, Neves NM, Gomes ME, Reis RL 2012: Synergistic effect of 
scaffold composition and dynamic culturing environment in multilayered systems for bone tissue engineering. J Tissue Eng Regen Med 6: e24-30

Salgado CL, Sanchez EM, Zavaglia CA, Granja PL 2012: Biocompatibility and biodegradation of polycaprolactonesebacic acid blended gels. J Biomed Mater Res A: 100: 243-251

Shalumon KT, Chennazhi KP, Nair SV, Jayakumar R 2013: High thick layer-by-layer 3D multiscale fibrous scaffolds for enhanced cell infiltration and its potential in tissue engineering. J Biomed Nanotechnol 9: 2117-2122

Valonen PK, Moutos FT, Kusanagi A, Moretti MG, Diekman BO, Welter JF, Caplan AI, Guilak F, Freed LE 2010: In vitro generation of mechanically functional cartilage grafts based on adult human stem cells and $3 \mathrm{D}$-woven poly(epsilon-caprolactone) scaffolds. Biomaterials 31: 2193-2200

Venugopal JR, Low S, Choon AT, Kumar AB, Ramakrishna S 2008: Nanobioengineered electrospun composite nanofibers and osteoblasts for bone regeneration. Artif Organs 32: 388-397

Venugopal J, Low S, Choon AT, Sampath Kumar TS, Ramakrishna S 2008: Mineralization of osteoblasts with electrospun collagen/hydroxyapatite nanofibers. J Mater Sci Mater Med 19: 2039-2046

Venugopal J, Prabhakaran MP, Zhang Y, Low S, Choon AT, Ramakrishna S 2010: Biomimetic hydroxyapatitecontaining composite nanofibrous substrates for bone tissue engineering. Philos Trans A Math Phys Eng Sci 28: $2065-2081$ 
Plate IX

Krbec M. et al.: Three-dimensional ... pp.77-83

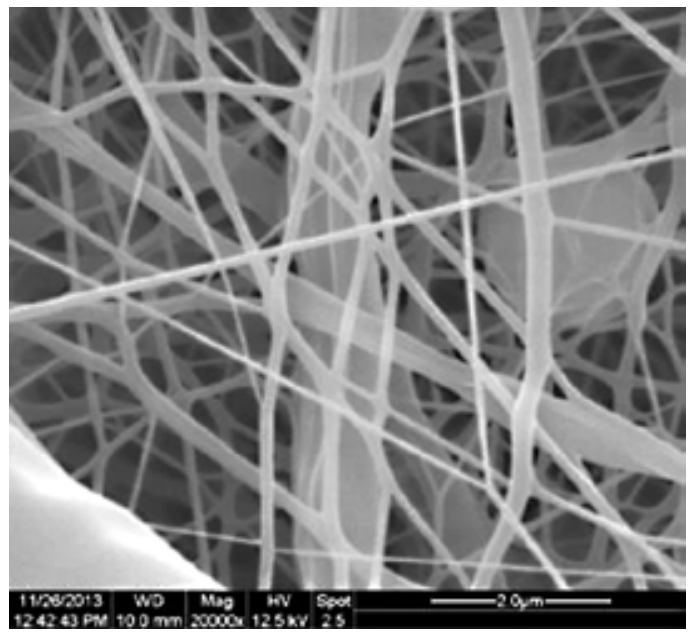

Fig. 1. Scanning electron microscopy picture of PCL nanofiber layer (magnification $\times 20,000$ )
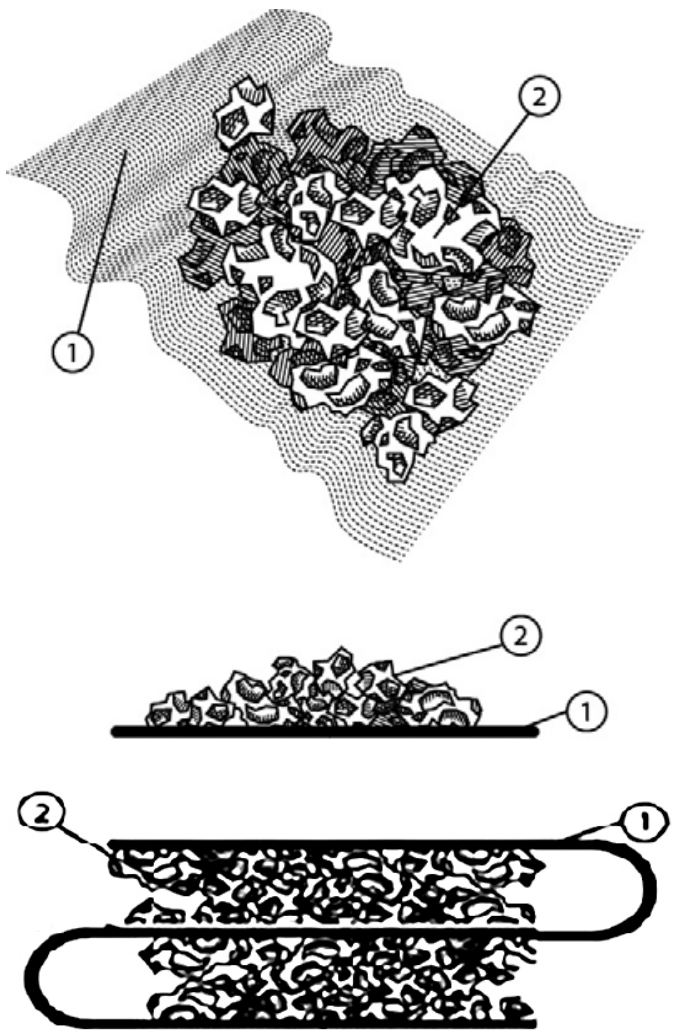

Fig. 3 a,b. Scheme of the PCL-Si-CaP-fibrin composite: 1 - nanofiber matrix, 2 - inorganic component fixed with fibrin glue. A top view, a side view (a), the possibility of layering (b) 


\section{Plate X}
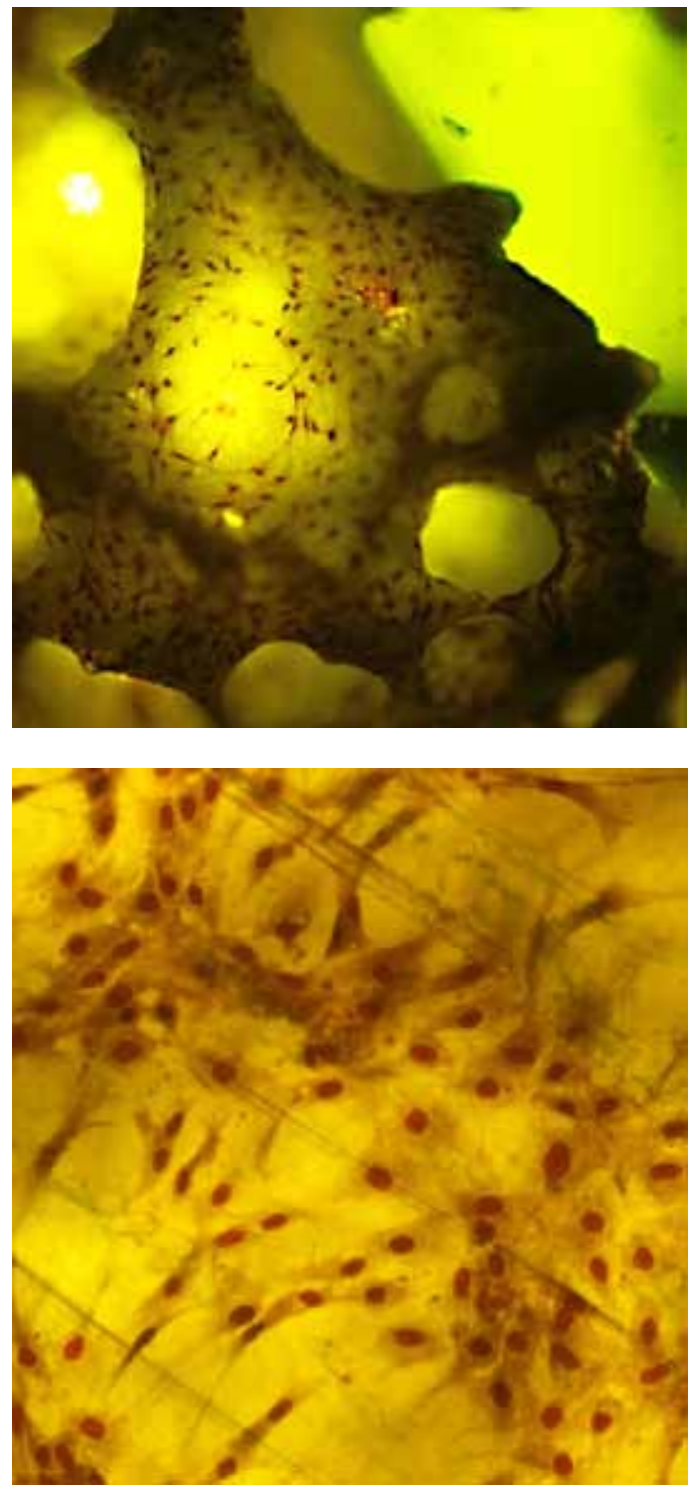

Fig. 4 a,b. Images of vital hMSC stained with May-Grünwald, Giemsa-Romanowski cultivated for 7 days in the expansion medium a) on Si-CaP crystals (magnification $\times 4$ ); b) on PCL nanofiber membrane (magnification $\times 10$ ). 


\section{Plate XI}

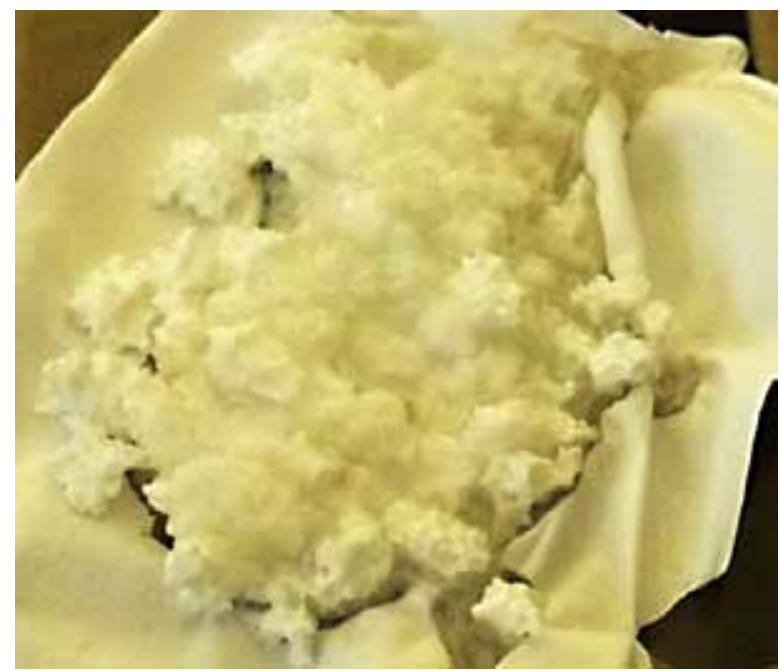

Fig. 5. PCL-Si-CaP-fibrin composite

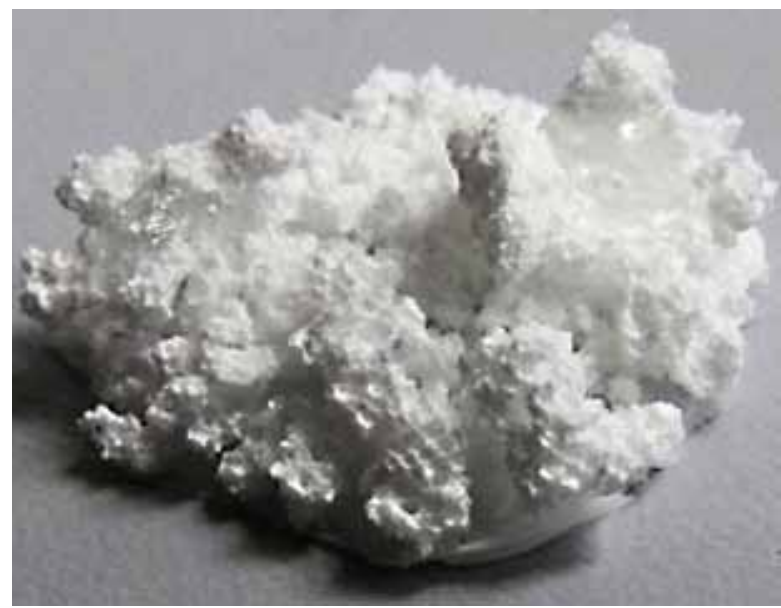

Fig. 6. PCL-Si-CaP-fibrin composite after processing, before colonisation with hMSC 